\title{
reALA
}

enero-agosto 2011

REVISTA CUATRIMESTRAL

ISSN: 1699-7476

Revista de Estudios

de la Administración

Local y Autonómica 


\section{Carta Editorial}

La Revista de Estudios de la Administración Local y Autonómica (REALA), publicada desde el año 1985 por el Instituto Nacional de Administración Pública (INAP), es la sucesora de la revista Estudios de la Vida Local (REVL), publicación iniciada por el Instituto de Estudios de Administración Local en 1942. Está dirigida a un público formado por académicos, investigadores, expertos y en general a todos aquellos profesionales interesados por los ámbitos del Gobierno y de la Administración local y autonómica. Tiene carácter multidisciplinar, especialmente en aquellas ciencias sociales que contribuyen a la comprensión del objeto de la revista: derecho, ciencia de la administración, ciencia política, gestión pública, sociología y economía.

\section{Objetivos}

- Mejorar la comprensión de los Gobiernos y las Administraciones y de las políticas públicas locales y autonómicas.

- Contribuir a la difusión del conocimiento sobre las diferentes aproximaciones al Gobierno y la Administración pública, la gestión pública y los cambios de la Administración local y autonómica en el contexto europeo y mundial.

- Enriquecer el debate científico a través de la publicación de estudios, experiencias y casos puestos en práctica por las Administraciones públicas locales y autonómicas.

- Favorecer el diálogo entre los diferentes profesionales dedicados al estudio y análisis del Gobierno y de la Administración local y autonómica: investigadores, expertos y funcionarios.

- Ayudar a los poderes públicos a mejorar su toma de decisiones ofreciendo elementos de evaluación y comparación sobre las reformas y mejoras en la gestión y la administración en España y en el extranjero.

- Desarrollar una visión comparativa en la aproximación al gobierno y a la administración local y autonómica.

\section{Funcionamiento}

La REALA se rige por un Consejo Asesor, formado por personalidades acreditadas por su relevante contribución en los ámbitos del gobierno y la administración local y autonómica, y un Consejo de Redacción, formado por expertos y académicos españoles y extranjeros de reconocido prestigio en los ámbitos de estudio de la revista.

\section{Periodicidad y contenido}

La REALA es una revista cuatrimestral, por lo que se publican tres números anualmente. El contenido de cada uno de los números sigue la siguiente estructura:

- Estudios: artículos teóricos sobre uno o varios temas.

- Experiencias y casos: artículos sobre innovaciones y debates en curso en la Administración española y europea.

- Documentos.

- Bibliografía: recensiones, notas e información.

El Consejo de Redacción podrá decidir que alguno de los números sea monográfico. 


\section{Modalidades de publicación}

Los artículos publicados en la REALA deben ser originales y se caracterizarán por su valor añadido y/o por su contribución al progreso del objeto de estudio. Los trabajos publicados, por tanto, no deben haber sido publicados previamente. Excepcionalmente se aceptarán trabajos relevantes ya publica- dos, siempre y cuando representen una contribución importante al conocimiento en las áreas objeto de la REALA, y su publicación previa se haya producido en una lengua no española.

En el supuesto de recibir trabajos inéditos en lengua no castellana, si éstos son evaluados positiva- mente, se publicarán traducidos.

REALA se publica en versión electrónica en el sitio web del INAP: $\underline{w w w . i n a p . e s}$

\section{Procedimiento de evaluación}

Todos los manuscritos enviados a la REALA para ser publicados, serán evaluados positivamente por el sistema del doble anónimo por, al menos, dos evaluadores, que emitirán un informe motivado. En el caso de informes divergentes se solicitará la evaluación a un tercer evaluador. El proceso de evaluación anónimo se aplicará a todos los originales propuestos para publicación en la REALA.

El Consejo de Redacción decidirá qué manuscritos serán publicados. El autor recibirá un informe de evaluación motivado por parte del Consejo en el que se comunicará si el manuscrito propuesto ha sido aceptado para su publicación, si ha sido aceptado bajo reserva de modificaciones o si ha sido rechazado. En el caso de que la publicación esté condicionada a la introducción de modificaciones, el autor se compromete a revisar el texto e introducir las modificaciones en el plazo indicado.

\section{Editorial Letter}

The Journal of Studies Local and Regional Administration (Revista de Estudios de la Administración Local y Autonómica, REALA), published since 1985 by the National Institute of Public Administration (INAP in Spanish), is the successor to the Local Life Studies journal (Estudios de la Vida Local, REVL), a publication started by the Institute of Local Administration Studies in 1942. It is aimed at readership made up of academics, researchers, experts and generally at all those professionals interested in the field of government and local and regional administration. It is multidisciplinary, particularly in those social sciences that contribute to understanding the subject matter of the journal: law, administrative sciences, political science, public management, sociology and economy.

\section{Objectives}

- To improve the understanding of governments, administrations and local and regional public policies.

- To contribute to popularising knowledge of the different ways to access or contact government and public administration, public management and the changes in local and regional administration in a European and world-wide context.

- To enrich scientific debate by publishing studies, experiences and cases put into practice by local and regional public administration.

- To encourage dialogue between different professionals dedicated to studying and analysing government and local and regional administrations: researchers, experts and civil servants.

- To help the public powers to improve their decision making by offering elements of evaluation and comparison on reforms and improvements to management and administration in Spain and abroad.

- To develop a comparative vision in means of accessing government and local and regional administrations. 


\section{Operation}

REALA is governed by an Advisory Board, made up of professionals accredited by their relevant contribution in the fields of government and local and regional administrations, and an Editorial Board, made up of Spanish and foreign experts and academics of renowned prestige in the fields of study of the journal.

\section{Periodicity and content}

REALA is a four-monthly journal, with three issues published each year. The content of each issue follows the following structure:

- Studies: theoretical articles on one or more subjects.

- Experiences and cases studies: articles on innovation and debates in progress in Spanish and European administration.

- Bibliography: reviews, notes and information.

The Editorial Board may decide to make any issue monographic.

\section{Types of publication}

The articles published in REALA must be original and are characterised by their added value and/or by their contribution to progress in the object of the study. Therefore, the works published in the journal must not have been published previously. Exceptionally, published works will be accepted as long as they represent an important contribution to knowledge in the areas object of REALA, and their previous publication was not in Spanish.

In the case of receiving unpublished work not written in Spanish, if these are positively evaluated, their translation will be published.

REALA is published in electronic version, on the Institute website: ww.inap.es

\section{Evaluation procedure}

All manuscripts sent to REALA to be published will be positively evaluated by the double anonymous system, by at least two evaluators who will issue a reasoned report. In the case of diverging reports, an evaluation will be requested from a third evaluator. The anonymous evaluation process will be applied to all the originals proposed for publication in REALA.

The Editorial Board will decide which manuscripts will be published. The author will receive a reasoned evaluation report from the Board, which will notify them if the proposed manuscript has been accepted for publication, if it has been accepted subject to modifications or if it has been rejected. Should publication be conditioned by the introduction of modifications, the author undertakes to revise the text and make the modifications in the period indicated. 
La revista de Estudios de la Administración Local y Autonómica (REALA) está incluida en la valoración integrada e índice de citas que realiza el CINDOC con las Revistas de Ciencias Sociales y Humanas (RESH), el IN-RECS tanto con las Revistas Españolas de Ciencias Sociales como con las de Ciencias Jurídicas -Derecho Administrativo- y figura en el catálogo de revistas de LATINDEX, DICE, DIALNET y CSIC.

Director del INAP: Manuel Arenilla Sáez

Directora de la Revista: Elisenda Malaret García (Universidad de Barcelona)

\section{Consejo Asesor}

Presidente: Ramón Martín Mateo (Universidad de Alicante).

Vocales: Francisco Clavijo Hernández (Universidad de La Laguna), Luis Cosculluela Muntaner (Universidad Complutense), Rafael Entrena Cuesta (Universidad de Barcelona), Pedro Escribano Collado (Universidad de Sevilla), Lorenzo Martín Retortillo (Universidad Complutense), Alfonso Pérez Moreno (Universidad de Sevilla), Juan Ramallo Massanet (Universidad Autónoma de Madrid), Ángel Sánchez Blanco (Universidad de Málaga).

\section{Consejo de Redacción}

Presidente: José Luis Carro Fernández-Valmayor (Universidad de Santiago de Compostela).

Vocales: Juan Arrieta Martínez de Pisón (Universidad Autónoma de Madrid), Jesús Colás Tenas (Diputación de Zaragoza), Antonio Embid Irujo (Universidad de Zaragoza), Francisco Javier García Roca (Universidad Complutense), Gérard Marcou (Université París I), Luis Ortega Álvarez (Universidad de Castilla-La Mancha), Tomás de la Quadra Salcedo y Fernández del Castillo (Universidad Carlos III), Joaquim Solé Vilanova (Universidad de Barcelona), Francisco Sosa Wagner (Universidad de León), Luciano Vandelli (Università di Bologna),

Francisco Velasco Caballero (Universidad Autónoma), Manuel Zafra Víctor (Universidad de Granada).

Secretaria de Redacción: Carmen Toscano Ramiro (Subdirección de Programas Formativos en Administración Local del INAP).

COORDINACIÓN:

Departamento de Publicaciones, Estudios y Documentación del INAP

REDACCIÓN YADMINISTRACIÓN: Atocha, 106, 28012 Madrid

Tel.: 91-273-91-19

e-mail: reala@inap.es

Catálogo general de publicaciones oficiales: http//www.publicacionesoficiales.boe.es

Fecha de entrada de este número en imprenta: 30 de noviembre de 2011

EDITA

INSTITUTO NACIONAL DE ADMINISTRACIÓN PÚBLICA

ISSN: $1699-7476$ (formato papel); 1989-8975 (formato electrónico)

NIPO: 635-12-010-X (formato papel); 635-12-011-5 (formato electrónico) DEPÓSITO LECAL: M-1.582-1958

Preimpresión: Lerko Print, S.A. Impresión: Publidisa

En esta publicación se ha utilizado papel reciclado libre de cloro de acuerdo con los criterios medioambientales de la contratación pública. 


\section{Sumario}

I. ESTUDIOS

Inmigración, federalismo y reglamentación Local en Estados Unidos Immigration Federalism and Local Regulation in the United States

\section{Laurie Reynolds}

Treinta años de Administración Autonómica en las Islas Baleares (Reflexiones sobre los cambios producidos por los Estatutos de Autonomía de 1983 y 2007) Thirty years of Autonomic Administration in the Balearic Islands (Reflections on the changes produced by the Statutes of Autonomy of 1883 and 2007)

\section{Joana M. Socias Camacho}

La participación autonómica y local en redes de cooperación europea The Involvement of Regional and Local Governments in European Cooperation Networks

\section{Luis Bouza García}

La primera década del conflicto en defensa de la Autonomía Local First decade of constitutional conflict in defense of Local Autonomy

\section{Santiago A. Roura Gómez}

El Partenariado Público y Privado Public-Private Partnership

\section{Maria Alessandra Sandulli}

El recurso especial en materia de contratación regulado en la Ley 34/2010, de 5 de agosto, actualmente incluida en la Ley 3/2011, de 14 de noviembre (TRLCSP) The Special Administrative Appeal in Public Sector Contracts given by Law 34/2010, of August 5th,amending Law 30/2007 of October 30th, actually included in Law 3/2011, November $14^{\text {th }}$

\section{José Manuel Martínez Fernández y Amaya Fernández García}

Desafíos de los entes locales: un nuevo modelo de gobierno con proyección exterior Challenges of local authorities: a new model of government with an exterior projection

\section{$M^{a}$ Remedios Zamora Roselló}

La reforma presupuestaria francesa: ¿cómo mantener un discurso sobre la calidad mientras la mayoría de los indicadores se centran en la eficacia? The French Budgetary Reform: "The Credibility of Quality Indicators"

\section{Roula Masou}

El Estatuto Básico del Empleado Público: proyección e incidencia en la Administración Local, cumplidos cinco años desde su aprobación The Civil Servant Basic Statute: projection and impact on local government, after five years from approval

\section{Agustín Díez Quesada}

\section{DOCUMENTOS}

A vuelta con la Torre Pelli: la polémica creada con la pretensión de exclusión de Patrimonio de la Humanidad de monumentos en Sevilla About the Pelli Tower: the controversy with the intention to exclude the world heritage the monuments of Seville

\section{Ángel Cabral González-Sicilia}

\section{BIBLIOGRAFÍA}

Josep Casadevall El convenio Europeo de Protección de los Derechos Humanos, el Tribunal de Estrasburgo y su jurisprudencia, Editorial Tirant Lo Blanch, Valencia 2012

(Recensión: Santiago Gonález-Varas Ibáñez) 
Mariela Iglesias, Marc Martí-Costa, Joan Subirats y Mariona Tomás (Eds.) Políticas urbanas en España. Grandes ciudades, actores y gobierno locales, Editorial Icaria, 2011, pp. 439.

(Recensión: Carmen Pineda Nebot)

Leonardo Avritzer y Fernando Filgueiras (orgs.) Corrupçao e sistema político no Brasil, Editorial Civilizaçâo Brasileira, 2011, pp. 239

(Recensión: Carmen Pineda Nebot)

Joseph S. Nye (Jr.) Las cualidades del líder, Editorial Paidós, Colección Estado y Sociedad. Barcelona, 2011, pp. 240

(Recensión: Ignacio Martín Granados)

Nogueira López, Alba (dir.) La termita Bolkeinstein, Mercado único vs. Derechos ciudadanos, Civitas, 2012, pp. 463

(Recensión: Andrea Garrido Juncal)

\section{AUTORES}

V. SUMARIOS DE OTRAS REVISTAS 